\title{
PEDIATRIC COCHLEAR IMPLANT RECIPIENTS IN INDIA: PARENTAL SATISFACTION WITH REHABILITATION SERVICES AND CORRELATION WITH OUTCOMES
}

\author{
Rabindra Pradhananga, John K. Thomas, Senthil Vadivu, Mohan Kameswaran \\ Department of Implantation Otology, Madras ENT Research Foundation, Chennai, India
}

Corresponding author: Rabindra Pradhananga, Department of Implantation Otology, Madras ENT Research Foundation, Chennai, India, e-mail: rabindrabp@yahoo.com

\begin{abstract}
Backround: Rehabilitation centres for cochlear implant (CI) recipients act as gateways for increasing auditory perception and developing speech and language. In the case of children, such centres must strive not only to get the best outcomes in terms of hearing and speech, but they must also provide satisfaction to both CI recipients and their parents. To gauge the quality of service, we have divided the range of services offered into four areas and have assessed the specific and overall satisfaction levels of parents of CI children towards these services.
\end{abstract}

\begin{abstract}
Material and methods: This was a prospective, randomized, cross-sectional study based on a questionnaire provided to CI users of rehabilitation centers in Tamil Nadu, India. The parents of $100 \mathrm{CI}$ recipients younger than 6 years were asked to fill in a questionnaire using a 5-point rating scale. The education level of the care-taker and the time spent with the child at home were also ascertained, and these factors were correlated with CI performance outcomes (categories of auditory performance, CAP, and speech intelligibility rating, SIR).
\end{abstract}

Results: The overall satisfaction level of the parents was reasonably high (mean $=3.9, \mathrm{SD}=0.44)$. There was a positive correlation of satisfaction score with rehabilitation outcomes ( $r=0.80$ for CAP; 0.29 for SIR). The level of education of the parents had no correlation with the outcome either for CAP $(r=0.15)$ or SIR $(r=0.07)$. Time spent by the parents with the CI recipient at home gave $r$-values of 0.31 for CAP and 0.39 for SIR.

Conclusions: The general level of satisfaction of parents towards the services provided by the rehabilitation centres was good. In terms of best CI outcome, the time spent by the parents with their child was more important than the parents' education level.

Keywords: auditory perception • cochlear implants • correction of hearing impairment $\bullet$ speech intelligibility

\section{IMPLANTES COCLEARES EN NIÑOS EN LA INDIA: SATISFACCIÓN DE LOS PADRES CON EL SERVICIO DE REHABILITACIÓN Y LA CORRELACIÓN DE LOS RESULTADOS}

\section{Resumen}

Introducción: Los centros de rehabilitación para los usuarios de implantes cocleares (CI) sirven de apoyo en el camino hacia la mejora del nivel de percepción auditiva y del desarrollo del habla y del lenguaje. En el caso de los niños, dichos centros deben esforzarse no sólo para los mejores resultados en términos de la mejora auditiva y del habla, sino también para la satisfacción tanto de los jóvenes usuarios de CI, como y de sus padres. Para medir la calidad de los servicios de rehabilitación, hemos dividido la gama de servicios ofrecidos en cuatro áreas y hemos evaluado los niveles específicos y generales de satisfacción de los padres de hijos con implantes cocleares en referencia a dichos servicios.

Material y métodos: Se ha realizado un estudio aleatorio, sumarial y prospectivo, basado en una encuesta a los usuarios de implantes cocleares en los centros de rehabilitación en Tamil Nadu (la India). A 100 padres de los niños menores de 6 años con implantes cocleares se les pidió que completaran una encuesta con una evaluación de escala de 5 puntos. Se ha tenido en cuenta el nivel de estudios de los padres y el tiempo que pasaban con su hijo en casa. Estos factores han sido correlacionados con la valoración de los resultados del funcionamiento del implante (categorías de evaluación auditiva-CAP, valoración del reconocimiento del habla-SIR).

Resultados: El nivel general de satisfacción de los padres ha sido bastante alto (media=3.9, $\mathrm{SD}=0.44$ ). Se ha observado una correlación positiva de la satisfacción con los resultados de la rehabilitación ( $r=0.80$ para CAP; 0.29 para SIR). Sin embargo, no se ha observado la correlación entre el nivel de estudios de los padres y los resultados, tanto para CAP ( $\mathrm{r}=0.15)$ como y 
para SIR ( $r=0.07)$. El tiempo que los padres pasaban en casa con sus hijos- usuarios de los implantes cocleares-fue de $\mathrm{r}=0.31$ para CAP y 0.39 para SIR.

Conclusiones: El nivel general de la satisfacción de los padres con los servicios de los centros de rehabilitación ha sido bueno. En cuanto a los mejores resultados de los implantes cocleares, el factor del tiempo pasado por los padres con sus hijos tuvo más relevancia que el nivel de sus estudios.

Palabras clave: percepción auditiva • implantes cocleares • corrección de defectos auditivos • comprensión del habla

\title{
КОХЛЕАРНЫЕ ИМПЛАНТАТЫ У ДЕТЕЙ В ИНДИИ: УДОВЛЕТВОРЕННОСТЬ РОДИТЕЛЕЙ РЕАБИЛИТАЦИОННЫМ ОБСЛУЖИВАНИЕМ И КОРРЕЛЯЦИЯ МЕЖДУ РЕЗУЛЬТАТАМИ
}

\section{Изложение}

Введение: Реабилитационные центры для пользователей кохлеарных имплантатов (CI) оказывают поддержку на пути к повышению уровня слухового восприятия, а также развития речи и языка. В случае детей такие центры должны стараться не только получать самые хорошие результаты в области слуха и речи, но также прилагать усилия для того, чтобы как молодые пользователи СI, так и их родители были удовлетворены. С целью определить качество реабилитационных услуг мы разделили оказываемые услуги на четыре группы и оценили подробные и общие уровни удовлетворенности родителей детей с кохлеарными имплантатами в контексте этих услуг.

\begin{abstract}
Материал и методы: Принимая во внимание будущее, в реабилитационных центрах в Тамил-Наду (Индия) было проведено с применением выборочного метода обзорное исследование, опирающееся на анкету для пользователей кохлеарных имплантатов. Родителей 100 детей младше 6 лет, пользующихся кохлеарными имплантатами, попросили заполнить анкету с 5-бальной шкалой оценок. Учитывался уровень образования опекуна и время, проводимое с ребенком дома. Данные факторы были соотнесены с оценкой результатов действия имплантата (категории восприятия слуха - CAP, рейтинг разборчивости речи - SIR).
\end{abstract}

Результаты: Общий уровень удовлетворенности родителей был соответственно высоким (среднее=3,9, $\mathrm{SD}=0,44)$. Установлена положительная корреляция между результатами удовлетворенности и результатами реабилитации ( $\mathrm{r}=0,80$ в случае CAP; 0,29 в случае SIR). Не замечено в свою очередь корреляции между уровнем образования родителей и результатами как в случае CAP $(\mathrm{r}=0,15)$, так и в случае SIR $(\mathrm{r}=0,07)$. Время, проводимое родителями дома с детьми, пользующимися кохлеарными имплантатами, составило r 0,31 в случае СAР и 0,39 в случае SIR.

Выводы: Общий уровень удовлетворенности родителей услугами реабилитационных центров был хорошим. Относительно лучших результатов кохлеарных имплантатов, время, которое родители посвящали ребенку, было более существенным чем уровень образования родителей.

Ключевые слова: слуховое восприятие • кохлеарные имплантаты • коррекция недостатков слуха • понимание речи

\section{IMPLANTY ŚLIMAKOWE U DZIECI W INDIACH: SATYSFAKCJA RODZICÓW Z OBSŁUGI REHABILITACYJNEJ ORAZ KORELACJA WYNIKÓW}

\section{Streszczenie}

Wprowadzenie: Ośrodki rehabilitacji dla użytkowników implantów ślimakowych (CI) służą jako wsparcie w drodze do zwiększenia poziomu percepcji słuchowej oraz rozwoju mowy i języka. W przypadku dzieci, takie ośrodki muszą starać się nie tylko o najlepsze wyniki w zakresie słuchu i mowy ale także o satysfakcję zarówno młodych użytkowników CI jak i ich rodziców. Aby zmierzyć jakość usług rehabilitacyjnych, podzieliliśmy zakres oferowanych usług na cztery obszary i oceniliśmy szczegółowe i ogólne poziomy satysfakcji rodziców dzieci z implantami ślimakowymi w kontekście tych usług.

Materiał i metody: Przeprowadzono prospektywne, losowe, przekrojowe badanie oparte na ankiecie dla użytkowników implantów ślimakowych w centrach rehabilitacyjnych w Tamil Nadu (Indie). Rodzice 100 dzieci poniżej 6 roku życia z implantami ślimakowymi zostali poproszeni o wypełnienie ankiety z 5-punktową skalą oceny. Uwzględniono poziom wykształcenia opiekuna oraz czas spędzany z dzieckiem w domu. Czynniki te zostały skorelowane z oceną wyników działania implantu (kategorie oceny słuchowej - CAP, ocena rozpoznawania mowy - SIR). 
Wyniki: Całkowity poziom satysfakcji rodziców był odpowiednio wysoki (średnia=3,9, SD=0,44). Stwierdzono pozytywną korelację wyniku satysfakcji z rezultatami rehabilitacji ( $\mathrm{r}=0,80$ dla CAP; 0,29 dla SIR). Nie zaobserwowano natomiast korelacji pomiędzy poziomem wykształcenia rodziców a wynikami zarówno dla CAP $(r=0,15)$ jak i SIR $(r=0,07)$. Czas jaki rodzice spędzali w domu ze swoimi dziećmi - użytkownikami implantów ślimakowych - wynosił wartość r 0,31 dla CAP i 0,39 dla SIR.

Wnioski: Ogólny poziom satysfakcji rodziców z usług centrów rehabilitacji był dobry. Odnośnie najlepszych wyników implantów ślimakowych, czas, który rodzice poświęcali dziecku, był istotniejszy niż poziom edukacji rodziców.

Słowa kluczowe: percepcja słuchowa • implanty ślimakowe • korekcja wad słuchu • rozumienie mowy

\section{Background}

Congenital hearing loss is not uncommon globally. For children afflicted by profound hearing loss, sound seems like a closed door which they long to open and opportunities for a better quality of life seem distant. But cochlear implant (CI) surgery, followed by a rigorous rehabilitation program, offers hope. Awareness of hearing loss, and early detection and diagnosis, are imperative for successful treatment of this problem and to ensure that the affected child can hear and communicate through speech. A rehabilitation program for children after cochlear implantation is an accepted part of the cochlear implant process. Indeed, it is very important to make the parents of a CI recipient understand why it is necessary to give comprehensive rehabilitation training after the surgery. A rehabilitation program will help the CI recipient utilize the auditory signal and to naturally integrate the various components of communication, which include listening, speech, language, reading, and thinking. Therefore, the CI recipient's rehabilitation centre is a gateway for increasing auditory perception and for developing speech and language.

In order to fully utilize rehabilitation centers, certain basic facilities are required for both the implantee and their attenders, usually the parents. Voluntary attendance of $\mathrm{CI}$ recipients to a rehabilitation centre is always preferred to coercion.

An expression of satisfaction or dissatisfaction is a judgment on the quality of service in all its aspects and whatever its strengths and limitations. An assessment of satisfaction gives an opportunity to find loopholes in the services offered and future rectification.

While the business community has been involved in assessing customer satisfaction for at least a decade, the medical community has lagged behind considerably in assessing patient satisfaction. More recent developments have prompted the health care profession to recognize patients as valuable customers. Nowadays medical groups have been more involved in this process, and providing services in a rehabilitation centre is also part of the medical profession. In India, there are only a few studies being carried out to measure, as a routine process, the satisfaction of patients with hospital services; in particular, assessment of satisfaction in a rehabilitation centre for CI recipients has not been reported.

The main aim of a rehabilitation centre is to lead a deaf child with a CI to speak and listen, a process which requires guiding and teaching the parents to apply certain techniques and strategies in everyday activities at home.
The therapist supports and guides the child and the parent to adapt to the sound provided by the cochlear implant. The rehabilitation center has to strive not only to get the best outcome but also to make sure that parents and CI recipients are satisfied.

There are established variables that affect outcomes: age at diagnosis and implantation, cause of hearing impairment, duration and degree of hearing impairment, associated syndromes in the child, intelligence and learning style of the child, skill of the therapist, and parent and family participation [1]. Due to cost, in developing countries most cochlear implantation is performed in middle and higher class families. However, efforts by the state government of Tamil Nadu, India, to provide funding, under the government health insurance scheme, to support cochlear implantation and 1 year of habilitation service, mean that low socioeconomic class families are now benefiting from cochlear implants. In this class of family, levels of awareness, education, and personal hygiene are low. Therefore we wanted to know whether the education level of the care giver (parent) and the time they spent with the child at home had any correlation with outcomes.

The study aimed to achieve following objectives:

- To assess the specific and overall satisfaction of the parents towards the services provided by the rehabilitation centers.

- To correlate the satisfaction level of the parent with the outcome regarding auditory perception and speech development after one year of habilitation program.

- To assess the education level of the parents and its correlation with outcomes.

- To correlate the time spent by a parent with the child at home with outcomes.

\section{Material and methods}

This was a prospective, randomized, questionnaire-based cross-sectional study performed at rehabilitation centers run by the MERF Institute of Speech and Hearing, Madras ENT Research Foundation, India. The Institute has established habilitation centers in four places in Tamil Nadu. The study was carried out in these centers from June to $\mathrm{Au}-$ gust 2014. The study protocol was approved by the Ethical Committee of the Institute (No. MERF-EC-AUG.14/010).

\section{Questionnaire design}

To get the best compliance on providing quality service, the centre has to fulfill certain basic needs such as adequate and appropriate teaching resources like toys, pictures, cards, puzzles, etc, well-trained therapists, convivial 


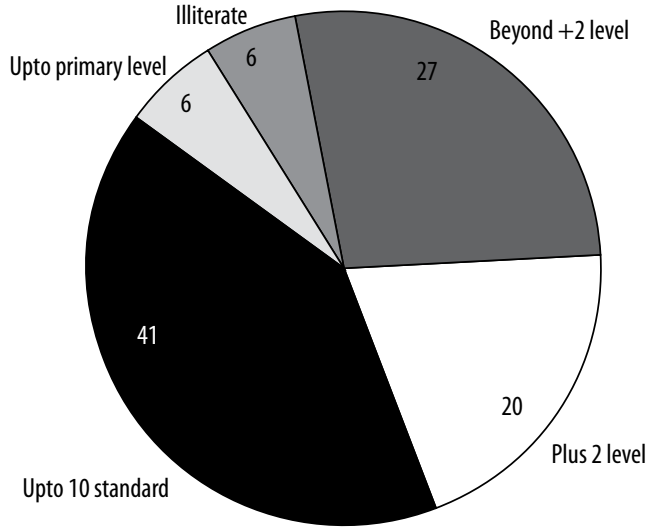

Figure 1. Education level of the parents

attitude from the staff, and a friendly environment. We divided all these needs into four categories to assess the satisfaction level. These were: a) quality of the therapy, b) quality of the services, c) environment of the centre, and d) adequacy of teaching resources. Based on these categories the questionnaire contained 12 questions, with 5 possible answers ranging from 'highly unsatisfied' (1) to 'highly satisfied' (5) on a 5-point Likert-type scale [2]. Additionally, there were two questions concerning the parental education level and the time spent by a parent with the child at home, in order to correlate their effect on outcomes. The questionnaire was designed in English and translated into the local Tamil language. The questionnaire was pre-tested (piloted) on a sample of 10 parents. The aim of the pilot study was to check that the issues were pertinent and the questions were clear, understandable, and comprehensible. As a result of the pilot study the layout of some questions was modified and further improvements were done.

\section{Data collection}

The data were collected from the parents of childhood CI recipients, children who were younger than 6 years and who were having training at one of the four rehabilitation centers. In total, 274 children were undergoing habilitation training in the centres during the time of the study. Parents of children who had completed more than 9 months of therapy were selected for the study through a convenience sampling method. A total 100 parents of CI recipient children, who were covered under the government health insurance scheme, were surveyed with the structured questionnaire. For illiterate parents, one of the implant fellows helped them to fill in the questionnaire.

The level of education of the parents (especially the caretaker) and the time spent with the child at home were also analysed. Outcomes were assessed on the basis of a Categories of Auditory Performance (CAP) score and a Speech Intelligibility Rating (SIR) score at the end of one year of rehabilitation training.

\section{Data analysis}

The statistical computer package SPSS version 17.0 was used to analyse the data. An ANOVA statistical test was

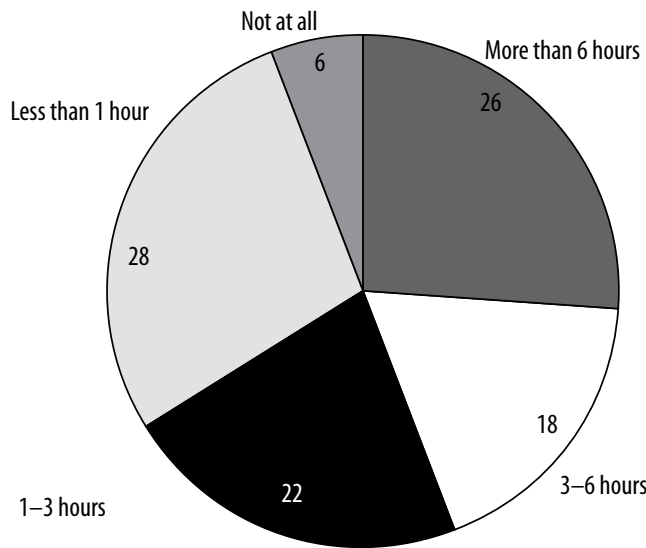

Figure 2. Time parents spend with $\mathrm{Cl}$ child (hours per day)

used to measure statistical differences among and between the categories of satisfaction. Correlation of satisfaction level with the outcomes of auditory perception (CAP) and speech and language development (SIR) was measured using the Spearman correlation test (with $r$ and $p$ values). The level of education of the parents was quantified into 5 groups as $1=$ illiterate, $2=$ studied up to primary school level ( $5^{\text {th }}$ standard), $3=$ up to secondary school level $\left(10^{\text {th }}\right.$ standard), $4=$ up to higher secondary $(+2)$ level, and $5=$ beyond +2 level. Similarly, the time the parent spent with the child was also quantified as $1=$ not at all, $2=$ less than 1 hour per day, $3=1-3$ hours, $4=3-6$ hours, and $5=$ more than 6 hours per day. Both variables were analyzed with outcomes separately using Spearman correlation coefficient test.

\section{Results}

The education level of the parents of CI recipients was relatively low, with the majority having education less than the $10^{\text {th }}$ standard (Figure 1 ). The study showed that time spent by the parents with implantees was variable. Some $28 \%$ of the parents spent less than 1 hour per day and $26 \%$ spent more than 6 hours per day (Figure 2).

The overall satisfaction level of the parents was quite high (mean $=3.9, \mathrm{SD}=0.44)$. The satisfaction level in each separate heading was almost the same. Adequate resources at the centre satisfied the most (mean $=4.34 ; \mathrm{SD}=0.55)$, whereas the quality of therapy (mean $=3.84 ; \mathrm{SD}=0.31)$; the quality of service (mean $=4.01 ; \mathrm{SD}=0.35$ ), and the environment of the centre (mean=3.74; $\mathrm{SD}=0.64$ ) also satisfied them. Table 1 shows in detail the satisfaction level in each field. An ANOVA statistical test showed that there was statistical significant difference among and between the categories of satisfaction $(F=12.468, p<0.05)$ (Table 2$)$.

On analysing the outcomes, the result of auditory perception (CAP score) showed that $13 \%$ achieved category $6,50 \%$ achieved category $5,36 \%$ achieved category 4 , and $1 \%$ achieved CAP 3 by the end of 12 months of habilitation training. Similarly, the result of speech and language development (SIR score) showed $2 \%$ achieved score $1,24 \%$ achieved score $2,50 \%$ had score $3,23 \%$ had 4 , and $1 \%$ had score 5 . 
Table 1. Satisfaction based on questionnaire results $(n=100)$

\begin{tabular}{|c|c|c|c|c|c|c|c|}
\hline & $\begin{array}{c}\text { Highly } \\
\text { dissatisfied }\end{array}$ & Dissatisfied & Neutral & Satisfied & $\begin{array}{c}\text { Highly } \\
\text { satisfied }\end{array}$ & Mean & Std dev \\
\hline \multicolumn{8}{|c|}{ Satisfaction Level on Quality of the Therapy (mean=3.84; $S D=0.31$ ) } \\
\hline Understandable & $0 \%$ & $0 \%$ & $43 \%$ & $37 \%$ & $20 \%$ & 3.77 & 0.7635 \\
\hline $\begin{array}{l}\text { Full utilisation of } 1 \mathrm{~h} \\
\text { session }\end{array}$ & $0 \%$ & $2 \%$ & $0 \%$ & $76 \%$ & $22 \%$ & 4.18 & 0.5199 \\
\hline $\begin{array}{l}\text { Perception of therapy by } \\
\text { implantees }\end{array}$ & $0 \%$ & $2 \%$ & $50 \%$ & $36 \%$ & $12 \%$ & 3.58 & 0.7272 \\
\hline \multicolumn{8}{|c|}{ Satisfaction Level on Quality of service (mean $=4.01 ; S D=0.35$ ) } \\
\hline Waiting time & $4 \%$ & $2 \%$ & $2 \%$ & $32 \%$ & $60 \%$ & 4.42 & 0.95 \\
\hline $\begin{array}{l}\text { Prior information if any } \\
\text { change in schedule }\end{array}$ & $2 \%$ & $14 \%$ & $20 \%$ & $32 \%$ & $32 \%$ & 3.78 & 1.106 \\
\hline Behavior of the staff & $0 \%$ & $0 \%$ & $51 \%$ & $33 \%$ & $16 \%$ & 3.65 & 0.744 \\
\hline Behavior of the therapist & $0 \%$ & $2 \%$ & $0 \%$ & $76 \%$ & $22 \%$ & 4.18 & 0.52 \\
\hline \multicolumn{8}{|c|}{ Satisfaction Level on Environment of the centre (mean $=3.74 ; S D=0.64)$} \\
\hline Play area for the kids & $0 \%$ & $8 \%$ & $50 \%$ & $24 \%$ & $18 \%$ & 3.52 & 0.882 \\
\hline Feeding area for the kids & $7 \%$ & $40 \%$ & $20 \%$ & $16 \%$ & $17 \%$ & 2.96 & 1.238 \\
\hline $\begin{array}{l}\text { Waiting area for the } \\
\text { parents }\end{array}$ & $0 \%$ & $0 \%$ & $25 \%$ & $47 \%$ & $28 \%$ & 4.03 & 0.731 \\
\hline Setting of therapy room & $0 \%$ & $0 \%$ & $10 \%$ & $35 \%$ & $55 \%$ & 4.45 & 0.67 \\
\hline \multicolumn{8}{|c|}{ Satisfaction Level on Adequate Teaching Resources at the centre } \\
\hline Adequacy of resources & $0 \%$ & $0 \%$ & $4 \%$ & $58 \%$ & $38 \%$ & 4.34 & 0.554 \\
\hline
\end{tabular}

Table 2. ANOVA results

\begin{tabular}{|c|c|c|c|c|c|}
\hline Group & \multicolumn{3}{|c|}{ Categories of satisfaction } & \multicolumn{2}{|c|}{$N$} \\
\hline 1 & \multicolumn{3}{|c|}{ Quality of the therapy } & \multicolumn{2}{|c|}{100} \\
\hline 2 & \multicolumn{3}{|l|}{ Quality of service } & \multicolumn{2}{|c|}{100} \\
\hline 3 & \multicolumn{3}{|c|}{ Environment of the center } & \multicolumn{2}{|c|}{100} \\
\hline \multirow[t]{2}{*}{4} & \multicolumn{3}{|l|}{ Teaching resources } & \multicolumn{2}{|c|}{100} \\
\hline & Sum of squares & Degrees of freedom & Mean square & Frequency & $p$-value \\
\hline Between & 20.752 & 3 & 6.917 & 12.468 & 0 \\
\hline Within & 219.692 & 396 & 0.555 & & \\
\hline Total & 240.444 & 399 & & & \\
\hline
\end{tabular}

Using the Spearman correlation coefficient test, the satisfaction level with the outcome was correlated with the auditory perception (CAP) score and the speech and language development (SIR) score. The $r$ values of satisfaction score with CAP and SIR score were 0.802 and 0.2927 respectively, with two-tailed values of $p$ of 0 and 0.003 respectively (Table 3 ). The association between the variables was statistically significant.

Similarly, analysing the correlation between the level of education of the parent with outcome, the value of $r$ was 0.1505 with CAP score, and -0.0720 with SIR score, with two-tailed values of $p$ being 0.1347 and 0.4762 respectively (Table 3 ). The association of education level with CAP and SIR scores was not statistically significant.

The time a parent spent with a CI recipient at home was found to be positively correlated with the outcome. The Spearman correlation coefficient $(r)$ between the time spent and CAP was 0.3092 and the two-tailed value of $p$ was 0.00175 ; with SIR it was 0.39152 and the two-tailed value of $p$ was $6 \mathrm{E}-05$. The values were statistically significant (Table 3 ). 
Table 3. Correlation among variables

\begin{tabular}{|c|c|c|c|}
\hline Correlation between & $r$ & $p$ & Association \\
\hline Total satisfaction score and CAP score & 0.8024 & 0 & significant \\
\hline Total satisfaction score and SIR score & 0.29277 & 0.00312 & significant \\
\hline Literacy and CAP score & 0.15059 & 0.13477 & not significant \\
\hline Literacy and SIR score & 0.07204 & 0.47628 & not significant \\
\hline Time spent and CAP Score & 0.30918 & 0.00175 & significant \\
\hline Time spent and SIR Score & 0.39152 & $6 \mathrm{E}-05$ & significant \\
\hline
\end{tabular}

\section{Discussion}

Auditory rehabilitation is crucial in achieving optimal outcomes for CI recipients. To develop spoken language through listening and to become an effective communicator, it is necessary for a child to participate in a comprehensive rehabilitation program. This program can be provided in a separate rehabilitation centre or in the same CI centre.

The rehabilitation centre is a mix of clinic and home or early childhood centre/school-based outreach service centre. It is better if an implant centre can establish this type of rehabilitation centre at different places over a wide geographical area so that implantees and their parents can train at a nearby centre. MERF is providing a rehabilitation training program from four various places covering a large area of Tamil Nadu. The survey was carried out in all four centers.

Satisfaction is a psychological concept that can be defined in different ways. Sometimes satisfaction is considered the judgment individuals make regarding any object or event after they have experienced it for some time [3]. Therefore the parents of CI recipients who had completed more than 9 months training were included in the survey.

Among the 3 points assessing satisfaction with 'quality of the therapy', we found the parents' satisfaction level was high for 'full utilization of 1 hour of session'. None of the parents were dissatisfied on 'understanding of the instruction given by the therapist'.

For the four points rating 'quality of service', most were highly satisfied with time management, with no long waiting times. They were more satisfied with the behavior of the therapist than of the other staff. This might be because more time was spent with the therapist than with others. Some were dissatisfied with not getting information in time on changes in schedule.

Among the four points on 'environment of the centre', parents were highly satisfied with 'the setting of the therapy room' and dissatisfied with 'feeding area for the kids'. The last point was included after the pilot study at the suggestion of some parents. Otherwise they were satisfied with 'play area for the kids' and 'waiting area. Although the teaching resources varied according to the age and interests of the child, most of the parents were highly satisfied or satisfied. This suggests that the centers have an adequate variety of resources to cover all age groups of CI recipients.
The education level of the parents was not high. This relates to most of the implantees coming from a low socioeconomic class, since the survey included those who had benefitted from the Tamil Nadu state government scheme for cochlear implantation. Some $6 \%$ were illiterate and answered the questionnaire with the help of one of the implant fellows.

Although, prior to the surgery, the importance of the parents' role at home was emphasised, only a few parents spent adequate time with their CI recipient child. As a measure of how parents neglected this aspect, some $6 \%$ did not spend any training time with the child at home. However, the time that a parent did spend with their child at home had a positive correlation with the outcome.

The overall outcomes in auditory perception and speech intelligibility were satisfactory. The majority of the implantees achieved category 5 , followed by category 6 by the end of the 12 months of habilitation training. Similarly, a majority achieved an SIR score of 3 in speech and language development. These results were similar with the result of the studies by Fang et al. and Ahn et al. $[4,5]$.

Other variables that can affect outcomes were beyond the scope of the study. Since all the children were less than 6 years old, outcomes were analysed in general. Previous studies examining parents' evaluations have concentrated largely on the parents' views and overall satisfaction regarding their child's outcome following cochlear implantation. These evaluations, generally using closedformat questionnaires, pertain to issues like children's communication skills, social relationships, and general functioning [6,7]. The majority of parents expressed high satisfaction with the implant's various outcomes [8]. Gascon-Ramos et al. [9] investigated parents' preferences and satisfaction with early intervention in deaf children. The study showed that mothers' educational background affected ratings on the supporting parents subscale, and there were significant correlations between the well-being of the mothers and their satisfaction scores.

\section{Conclusions}

The specific and overall satisfaction of parents towards the services provided by the rehabilitation centers was found to be one of general satisfaction. The role of the parent was found to be vital in obtaining the optimum outcome after successful implantation. The education level of the 
parents did not have much effect on getting the optimum outcome after a CI.

After a cochlear implantation, rehabilitation training is the backbone of a CI program to convert a non-speaking child to a speaking child. To satisfy the parents, the rehabilitation centre must provide quality service. The quality of therapy sessions also needs to be appropriate, meaningful, and fun so that the implant user will be motivated to participate. Parents also have to be encouraged to become the primary facilitators of their child's listening and speech development.

\section{Acknowledgement}

We thank all the involved parents of CI recipients for their support and time.

\section{References:}

1. Zwolan TA. Selection of cochlear implant candidates. In Cochlear Implants. $2^{\text {nd }}$ Ed. New York, Thieme Medical Publishers, 2006: 57-63.

2. Likert R. A technique for the measurement of attitudes. Archives of Psychology, 1932; 140: 1-55.

3. Chakraborty R, Majumdar A. Measuring consumer satisfaction in health care sector: the applicability of SERVQUAL. Researchers World, 2011; 2(4): 17.

4. Fang HY, Ko HC, Wang NM, Fang TJ, Chao WC, Tsou YT et al. Auditory performance and speech intelligibility of Mandarin-speaking children implanted before age 5. Int J Pediatr Otorhinolaryngol, 2014; 78(5): 799-803.

5. Ahn JH, Lee KS. Outcomes of cochlear implantation in children with CHARGE syndrome. Acta Otolaryngol, 2013; 133(11): 1148-53.
6. Archbold S, Lutman ME, Gregory S, O'Neill C, Nikolopoulos TP. Parents and their deaf child: their perceptions three years after cochlear implantation. Deafness and Education International, 2002; 4(1): 12-40.

7. O’Neill C, Lutman ME, Archbold SM, Gregory S, Nikolopoulos TP. Parents and their cochlear implanted child: questionnaire development to assess parental views and experiences. Int J Pediatr Otorhinolaryngol, 2004; 68: 149-60.

8. Incesulu A, Vural M, Erkam U. Children with cochlear implants: parental perspective. Otol Neurotol, 2003; 24: 605-11.

9. Gascon-Ramos M, Campbell M, Bamford J, Young A. Influences on parental evaluation of the content of early intervention following early identification of deafness: a study about parents' preferences and satisfaction. Child Care Health Dev, 2010; 36(6): 868-77. 